\title{
PENGARUH ENDORPHINE MASSAGE TERHADAP SKALA INTENSITAS NYERI PADA IBU BERSALIN NORMAL PRIMIPARA INPARTU KALA I DI PMB KOTA BENGKULU TAHUN 2020
}

\author{
Wewet Savitri ${ }^{1}$, Nispi Yulyana ${ }^{2}$, Anisah Tifani Maulidyanti ${ }^{3}$ \\ Program Studi Kebidanan Program Sarjana Terapan, Poltekkes Kemenkes Bengkulu ${ }^{123}$ \\ Email: ${ }^{3}$ anisatifani800@gmail.com
}

\begin{abstract}
Pain in labor is a manifestation of uterine contractions in the first stage of labor that can cause fatigue so that it causes a decrease in uterine contractions. Many methods are offered to reduce pain during labor, non pharmacologically including endorphine massage has been proven to increase the ability of mothers to tolerate pain during childbirth. The purpose of this study was to determine the effect of endorphine massage on pain intensity scale in first-time normal mothers in PMB Bengkulu City in 2020. This study used quasi-experimental designs with the pretest-posttest Non Equivalent Control Group. The intervention group the endorphine massage was given to first stage mothers, while the control group was given deep breath relaxation techniques. Total sample are 30 people, divided into 2 groups, each each of which amounted to 15 people. The statistical analysis used was the Wilcoxon test and the Mann-Whitney Test. The results of thetest Wilcoxon showed that the average value of pain intensity in the first stage before and after the intervention was 7.53 and it became 6.00 with a p-value $=0.000(<0.05)$. whereas in the control group the average value was 7.20 and after being treated it became 6.00 with a p-value $=0.001(<0.05)$ which means that there was an influence of endorphine massage on the intensity scale of pain in first-time normal primipara delivery mothers in PMB Bengkulu City. It is expected that midwives can pay more attention to maternal needs for comfort by applying endorphine massage in the control of labor pain.
\end{abstract}

Keywords : Labor, Labor Pain, Endorphine Massage

\begin{abstract}
Abstrak
Rasa nyeri pada persalinan merupakan manifestasi dari adanya kontraksi uterus pada kala I persalinan yang dapat mengakibatkan keletihan sehingga menyebabkan penurunan kontraksi uterus. Banyak metode yang ditawarkan untuk menurunkan nyeri pada saat persalinan, secara nonfarmakologi antara lain pemberian Endorphine massage telah terbukti meningkatkan kemampuan ibu untuk mentoleransi nyeri selama melahirkan. Tujuan penelitian ini adalah untuk mengetahui pengaruh endorphine massage terhadap skala intensitas nyeri pada ibu bersalin normal inpartu kala I di PMB Kota Bengkulu Tahun 2020. Penelitian ini merupakan penelitian quasi experiment designs dengan pendekatan pretest-posttest Non Equivalent Control Group. Pada kelompok intervensi diberikan perlakuan endorphine massage pada ibu bersalin kala I. sedangkan pada kelompok kontrol diberikan perlakuan teknik relaksasi nafas dalam. Jumlah sampel sebanyak 30 orang yang dibagi menjadi 2 kelompok yang masing-masing berjumlah 15 orang. Analisis statistic yang digunakan adalah uji Wilcoxon dan uji Mann-Whitney Test. Hasil penelitian dengan uji Wilcoxon menunjukkan nilai rata-rata intensitas nyeri kala I sebelum dan sesudah diberikan intervensi sebesar 7.53 dan menjadi 6.00 dengan nilai p-value $=0.000(<0.05)$. sedangkan pada kelompok control nilai rata-rata 7.20 dan setelah diberikan perlakuan menjadi 6.00 dengan nilai pvalue $=0.001 \quad(<0.05)$ yang berarti bahwa ada pengaruh endorphine massage terhadap skala intensitas nyeri pada ibu bersalin normal primipara inpartu kala I di PMB Kota Bengkulu.
\end{abstract}

Kata kunci: Persalinan, Nyeri Persalinan, Endorphine Massage 


\section{Vol. 16 No.2 Mei - Agustus 2021}

\section{PENDAHULUAN}

Kehamilan, persalinan dan masa nifas merupakan suatu peristiwa fisiologis dalam setiap perkembangan bagi wanita yang akan menjadi ibu. Peristiwa fisiologis ini dapat berubah menjadi patologis atau trauma pada ibu karena nyeri yang dialaminya. Beberapa ibu bahkan ada yang trauma untuk hamil dan melahirkan lagi karena takut akan mengalami nyeri yang sama. Bagi ibu yang pernah melahirkan, nyeri persalinan merupakan nyeri yang paling menyakitkan apalagi bagi ibu yang baru pertama kali merasakannya. ${ }^{6}$

Menurut Humaira, di Amerika Serikat $70 \%$ sampai $80 \%$ ibu yang melahirkan mengharapkan persalinan berlangsung tanpa rasa nyeri. Di Indonesia, persentase operasi seksio sesaria sekitar 5\%. Dirumah sakit pemerintah rata-rata $11 \%$, sementara dirumah sakit swasta sekitar 20\% hingga 50\%. ${ }^{7}$

Rasa nyeri diperlukan untuk mengenali adanya kontraksi uterus selama proses persalinan, tetapi kadang rasa nyeri tersebut bisa menimbulkan akibat patologis yang dirasakan terus menerus, ditambah rasa cemas dan ketakutan yang dialami ibu bersalin. Hal ini dapat mengakibatkan keletihan sehingga mengakibatkan penurunan kontraksi uterus dan proses persalinan pun berlangsung lebih lama. Persalinan yang lama dapat membahayakan ibu dan janin. Partus lama merupakan penyebab partus macet yang merupakan salah satu penyumbang kematian pada ibu bersalin $(1,8 \%)^{2}$

Cara menghilangkan nyeri persalinan dapat dilakukan secara medis dan non medis. Cara menghilangkan nyeri persalinan secara medis adalah dengan menggunakan pethidine, anestesi epidural, entonox, dan TENS (Transcutaneous electrical nerve stimulation). Tindakan ini sudah banyak digunakan di beberapa rumah sakit di Indonesia untuk membantu ibu dalam proses melahirkan. Teknik non medis lainnya adalah massage atau pijat dan teknik relaksasi nafas dalam. Pijat cara lembut membantu ibu merasa lebih segar, rileks dan nyaman selama persalinan. Dalam persalinan, massage juga membuat ibu merasa lebih dekat dengan orang yang merawatnya. Sentuhan seseorang yang peduli dan ingin menolong merupakan sumber kekuatan saat ibu sakit, lelah atau takut. ${ }^{13}$

Endorphine massage merupakan sebuah terapi sentuh atau pijatan ringan yang diberikan pada wanita hamil menjelang persalinan. ${ }^{10}$ Dikarenakan pijatan merangsang tubuh untuk melepaskan senyawa endorphine yang merupakan pereda rasa sakit dan dapat menciptakan perasaan nyaman. ${ }^{3}$

Pemberian Endorphine massage telah terbukti meningkatkan kemampuan ibu untuk mentoleransi nyeri selama melahirkan. Sebagaimana penelitian yang dilakukan oleh, ${ }^{5}$ bahwa ada pengaruh pemberian pijat endorphine terhadap intensitas nyeri kala I pada ibu primipara. Sedangkan hasil penelitian, 11 mendapatkan hasil bahwa terdapat perubahan dari sebelum diberikan perlakuan endorphine massage rata-rata terdapat nyeri berat berubah menjadi rata-rata nyeri sedang setelah diberikan perlakuan endorpine massage.

Relaksasi merupakan suatu tindakan untuk membebaskan mental dan fisik dari ketegangan dan stress sehingga dapat meningkatkan toleransi nyeri. ${ }^{1}$ Penelitian yang telah dilakukan Taqwin, bahwa teknik relaksasi nafas dalam berpengaruh terhadap persepsi nyeri dan kemampuan control diri pada ibu tentang proses persalinan, ibu yang belum bisa mengendalikan nyeri yang dirasakan dalam proses persalinan akan sulit mengontrol nyeri yang dirasakan terkait belum adanya penanganan nyeri yang didapatkan yaitu teknik relaksasi nafas dalam. Oleh karena itu, teknik relaksasi nafas dalam dapat digunakan sebagai intervensi dalam asuhan kebidanan ibu bersalin kala I untuk mengurangi nyeri persalinan. ${ }^{16}$

Tujuan penelitian ini adalah mengetahui pengaruh endorphine massage terhadap skala intensitas nyeri pada ibu bersalin normal primipara inpartu kala I di PMB Kota Bengkulu Tahun 2020.

\section{METODE}

Jenis Penelitian yang digunakan adalah quasi experiment designs dengan pendekatan kuantitatif. Teknik pengambilan sample yang digunakan yaitu Purposive sampling.

Sampel dalam penelitian ini ditemukan dengan menggunakan non probability 
sampling yaitu dengan teknik purposive sampling. Sampel terdiri dari dua kelompok yaitu kelompok perlakuan dan kelompok pembanding, masing-masing kelompok terdiri dari 15 orang sehingga sampel berjumlah 30 orang. Rumus sampel :

$$
\mathrm{n}=\frac{2 \sigma^{2}\left[\mathrm{z}_{1-\alpha / 2}+\mathrm{z}_{1-\beta}\right]^{2}}{\left(\mu_{1}-\mu_{2}\right)^{2}}
$$

Keterangan rumus :

$\mathrm{Z}_{1-\alpha / 2}$ : Standar normal deviasi untuk $\alpha$ (dilihat pada tabel distribusi $\mathrm{Z}$

$\mathrm{Z}_{1-\beta}$ : Standar normal deviasi untuk $\beta$ (dilihat pada tabel distribusi $\mathrm{Z}$

$\sigma^{2}$ : Estimasi varian kedua kelompok berdasarkan literatur

$\mu_{1}$ : Nilai mean kelompok kontrol yang didapat dari literatur atau berdasarkan pengalaman peneliti

$\mu_{2}$ : Nilai mean kelompok perlakuan yang didapat dari literatur atau berdasarkan pengalaman peneliti

$\mu_{1}-\mu_{2}$ : Beda nilai mean yang dianggap bermakna secara klinik antara dua kelompok

\section{HASIL}

Penelitian ini dilakukan untuk mengetahui pengaruh endorphine massage terhadap skala intensitas nyeri pada ibu bersalin normal inpartu kala I di PMB Kota Bengkulu, dengan hasil pengolahan data sebagai berikut:

Tabel 1. Distribusi Frekuensi Karateristik Ibu Bersalin berdasarkan Usia dan Penolong di PMB Kota Bengkulu

\begin{tabular}{lllll} 
Pre Test & 7.53 & 0.640 & 7 & 9 \\
Post Test & 6.00 & 0.756 & 5 & 7 \\
\hline
\end{tabular}

Berdasarkan table 2 menunjukkan ratarata intensitas nyeri kala I fase aktif ibu bersalin sebelum diberikan perlakukan endorphine massage sebesar (7.53) dan setelah diberikan perlakuan endorphine massage menurun menjadi (6.00).

Tabel 3. Rata-Rata Intensitas Nyeri Kala I Fase Aktif Pada Ibu Bersalin Sebelum dan Setelah Dilakukan dan Teknik Relaksasi Nafas Dalam di Ruang Bersalin PMB Kota Bengkulu

\begin{tabular}{lcccc}
\hline $\begin{array}{c}\text { Teknik Relaksasi } \\
\text { Nafas Dalam }\end{array}$ & Mean & SD & Min & Max \\
\hline Pre Test & 7.20 & 0.775 & 6 & 8 \\
Post Test & 6.00 & 0.845 & 5 & 7 \\
\hline
\end{tabular}

Berdasarkan tabel 3 menunjukkan ratarata intensitas nyeri kala I fase aktif ibu bersalin sebelum diberikan perlakukan teknik relaksasi nafas dalam sebesar (7.20) dan setelah diberikan perlakuan teknik relaksasi nafas dalam menurun menjadi (6.00).

Tabel 4. Uji Normalitas Data

\begin{tabular}{lccc}
\hline \multicolumn{1}{c}{ Variabel } & \multicolumn{3}{c}{ Shapiro- Wilk } \\
& Statistic & Df & Sig. \\
\hline Endorphine & & & \\
Massage & & & \\
Nyeri Sebelum & 0.744 & 15 & 0.001 \\
Nyeri Sesudah & 0.823 & 15 & 0.007 \\
\hline Teknik & & & \\
\hline
\end{tabular}

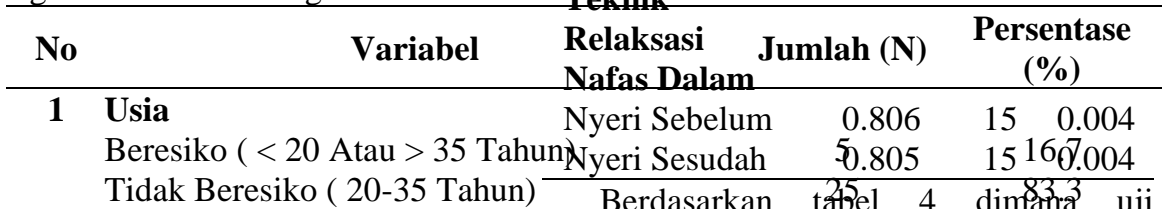

2 Penolong normalitas menggunakan uji Shapiro-Wilk Bidan dengan Non APN didapatkan nilai 1tgnifikansi 367riabel Bidan dengan APN sebelum intervensi nilal signifikans $\{333,30,001$ Total dan setelah interven 30 nilai signiflfdhsi =

Berdasarkan tabel 1, didapatkan bahwa sebagian besar responden $(83.3 \%)$ memiliki usia tidak berisiko yaitu 20-35 tahun dengan penolong bersalin merupakan bidan dengan APN $(63.3 \%)$.

Tabel 2. Rata-Rata Intensitas Nyeri Kala I Fase Aktif Pada Ibu Bersalin Sebelum dan Setelah Dilakukan Endorphine Massage di Ruang Bersalin PMB Kota Bengkulu dan setelah interven $\mathbf{3 0}$ nilai signif104hsi $=$
0,007 . Nilai signifikansi variabel kontrol sebelum diberikan perlakuan nilai signifikansi $=0,004$ dan setelah diberikan perlakuan nilai signifikansi $=0,004$. Hal ini berarti nilai signifikansi $<0,05$ yang menunjukkan bahwa data berdistribusi tidak normal, maka tidak dapat dilanjutkan dengan melakukan Paired $t$ test, melainkan menggunakan uji Wilcoxon untuk melihat perbedaan penurunan nyeri sebelum dan sesudah pada variabel intervensi dan variabel

Endorphine Massage Mean SD Mliontwax Beda


Vol. 16 No.2 Mei - Agustus 2021

Tabel 5. Uji Normalitas Data

\begin{tabular}{lccc}
\hline \multirow{2}{*}{ Variabel } & \multicolumn{3}{c}{ Shapiro- Wilk } \\
& Statistic & Df & Sig. \\
\hline $\begin{array}{l}\text { Nyeri } \\
\text { Sebelum }\end{array}$ & 0.838 & 30 & 0.000 \\
$\begin{array}{l}\text { Nyeri } \\
\text { Sesudah }\end{array}$ & 0.808 & 30 & 0.000 \\
\hline
\end{tabular}

Berdasarkan pada tabel 5 dimana uji normalitas untuk mengetahui pengaruh endorphine massage terhadap skala intensitas nyeri pada ibu bersalin normal inpartu kala I menggunakan uji Shapiro-Wilk didapatkan nilai signifikansi variabel nyeri sebelum nilai signifikansi $=0,000$ dan pada variabel nyeri sesudah nilai signifikansi $=0,000$. Hal ini berarti nilai signifikansi $<0,05$ yang menunjukkan bahwa data berdistribusi tidak normal, maka tidak dapat dilanjutkan dengan melakukan Independent sample $T$ - test, melainkan menggunakan uji Mann-Whitney Test untuk melihat pengaruh endorphine massage terhadap skala intensitas nyeri pada ibu bersalin normal inpartu kala I.

Tabel 6. Rata-Rata Intensitas Nyeri Kala I Fase Aktif Pada Ibu Bersalin Sebelum dan Setelah Dilakukan Endorphine Massage dan Teknik Relaksasi Nafas Dalam di Ruang Bersalin PMB Kota Bengkulu

nilai beda 1,20 memiliki nilai $p$-value $0.001<$ 0.05 yang berarti terdapat pengaruh antara rasa nyeri sebelum dan sesudah diberikan pemberian teknik relaksasi nafas dalam.

Tabel 7. Perbedaan Kelompok Intervensi Dan Kelompok Kontrol Terhadap Penurunan Skala Intensitas Nyeri Pada Ibu Bersalin Normal Inpartu Kala I Di PMB Kota Bengkulu

\begin{tabular}{lccccc}
\hline \multicolumn{1}{c}{ Variabel } & \multicolumn{4}{c}{ Penurunan Skala Nyeri } \\
& N & Mean & SD & Bedap value \\
\hline $\begin{array}{l}\text { Post Test Endorphine } \\
\text { Massage }\end{array}$ & 15 & 6.00 & 0.756 & & \\
$\begin{array}{l}\text { Post Test Teknik } \\
\text { Relaksasi Nafas }\end{array}$ & & & \multicolumn{2}{c}{0.00} & 0.000 \\
Dalam & 15 & 6.00 & 0.845 & & \\
\hline
\end{tabular}

Berdasarkan table 7, analisis uji statistic non parametric dengan menggunakan Uji Mann-Whitney Test dengan tingkat kepercayaan 95\% $(\alpha=0.05)$ diperoleh perbedaan nilai mean antara perlakuan endorphine massage dan teknik relaksasi nafas dalam sebesar 0.00 dengan penurunan endorphine massage sebesar 6.00 dan teknik relaksasi nafas dalam sebesar 6.00 dengan nilai $\mathrm{p}$-value adalah 0.000 dengan demikan pvalue $<\alpha(0.000<0.05)$, maka Ha diterima dan dapat disimpulkan bahwa ada pengaruh $\boldsymbol{P}$ - kelompok intervensi dan kelompok control

Valterhadap penurunan skala intensitas nyeri \begin{tabular}{lrlllll|l}
\hline Endorphine Massage & & \multicolumn{5}{c}{ pada ibu bersalin normal inpartu kala I di } \\
Sebelum & 7.53 & 0.640 & 7 & 9 & 1. & PMB Kota Bengkulu. \\
Setelah & 6.00 & 0.756 & 5 & 7 & 53 & 0.000 & Hasil deskriptif diperoleh rasa nyeri
\end{tabular} Relaksasi Nafas Dalam setelah diberikan perlakuan endorphine $\begin{array}{lllllll}\text { Sebelum } & 7.20 & 0.775 & 6 & 8 & 1 . & \text { ma\$sage yaitu } 6 \text { dan pada teknik relaksasi }\end{array}$

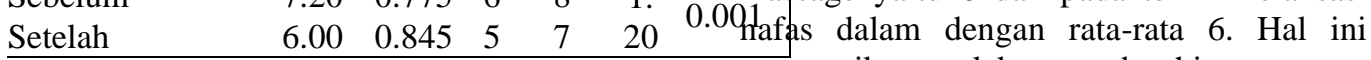

Berdasarkan tabel 6 menunjukkan bahwa rata-rata intensitas nyeri kala I fase aktif ibu bersalin sebelum dilakukan endorphine massage sebesar 7,53 dan setelah dilakukan endorphine massage rata-rata intensitas nyeri kala I fase aktif ibu bersalin menurun menjadi 6,00 dengan nilai beda 1,53 dan memiliki nilai $p$-value $0.000<0.05$ yang berarti terdapat pengaruh antara rasa nyeri sebelum dan sesudah diberikan pemberian endorphine. Pada pasien sebelum dilakukan teknik relaksasi nafas dalam diperoleh ratarata nyeri sebesar 7,20 dan setelah dilakukan teknik relaksasi nafas dalam mengalami penurunan tingkat nyeri sebesar 6,00 dengan mengartikan perlakuan endorphine massage dan teknik relaksasi nafas dalam memberikan penurunan skala nyeri yang sama. Dari hasil tersebut dapat disimpulkan bahwa tidak terdapat perbedaan antara rasa nyeri sesudah diberikan perlakuan endorphine massage dan teknik relaksasi nafas dalam terhadap penurunan skala nyeri pada ibu bersalin normal inpartu kala I di PMB Kota Bengkulu.

Tabel 8. Hubungan Usia Terhadap Penurunan Nyeri Pada Ibu Bersalin Normal Inpartu Kala I di PMB Kota Bengkulu 


\begin{tabular}{|c|c|c|}
\hline & \multicolumn{2}{|c|}{ Variabel } \\
\hline \multirow{2}{*}{ Spearman's rho } & Umur & $\begin{array}{l}\text { Correlatic } \\
\text { Sig. (2-ta } \\
\text { N }\end{array}$ \\
\hline & $\begin{array}{l}\text { Intervensi } \\
\text { yang } \\
\text { dilakukan }\end{array}$ & $\begin{array}{l}\text { Correlatic } \\
\text { Sig. (2-ta } \\
\text { N }\end{array}$ \\
\hline \multicolumn{3}{|c|}{$\begin{array}{l}\text { Berdasarkan table } 8 \text { menunjukkan } \\
\text { bahwa nilai signifikansi atau Sig. (2-tailed) } \\
0.685>0.05 \text { dapat diartikan bahwa tidak ada } \\
\text { hubungan yang signifikan (berarti) antara } \\
\text { variabel umur responden dengan intervensi } \\
\text { yang dilakukan. Pada koefisien korelasi } \\
\text { sebesar 0.077 artinya, tingkat kekuatan } \\
\text { hubungan (korelasi) antara variabel umur } \\
\text { responden dengan intervensi yang dilakukan } \\
\text { adalah sebesar } 0.077 \text { atau korelasi sangat } \\
\text { lemah. }\end{array}$} \\
\hline
\end{tabular}

Tabel 9 Hubungan Penolong Terhadap Penurunan Nyeri Pada Ibu Bersalin Normal Inpartu Kala I di PMB Kota Bengkulu

\begin{tabular}{lll}
\multicolumn{3}{c}{ PMB Kota Bengkulu } \\
\hline & \multicolumn{2}{c}{ Variabel } \\
\hline & Penolong & $\begin{array}{l}\text { Correlation Coeffici } \\
\text { Sig. (2-tailed) }\end{array}$ \\
Spearman's rho & & $\mathrm{N}$ \\
\cline { 2 - 4 } & $\begin{array}{ll}\text { Intervensi } \\
\text { yang } \\
\text { dilakukan }\end{array}$ & $\begin{array}{l}\text { Correlation Coeffic } \\
\text { Sig. (2-tailed) }\end{array}$ \\
\hline
\end{tabular}

Berdasarkan table 9 menunjukkan bahwa nilai signifikansi atau Sig. (2-tailed) $0.750>0.05$ dapat diartikan bahwa tidak ada hubungan yang signifikan (berarti) antara variabel penolong dengan intervensi yang dilakukan. Sedangkan pada koefisien korelasi sebesar 0.061 artinya, tingkat kekuatan hubungan (korelasi) antara variabel penolong dengan intervensi yang dilakukan adalah sebesar 0.061 atau korelasi sangat lemah. Nilai koefisien korelasi bernilai negative, maka hubungan antara variabel penolong dan variabel intervensi yang dilakukan tidak searah.

\section{PEMBAHASAN}

Berdasarkan hasil analisis data yang telah dilakukan maka dijabarkan karakteristik ibu bersalin normal inpartu kala I sebagai berikut ini:

\section{Pengarubmutisia Ihtehrdapi yasigala Intensitas Nyeri PadglillbmkBarsalin Normal Inpartu Kala I}

Responden dadam penelitian ini adatah ibu bersalin normal inpartu kala I fase aktif dan didapatkan jumlah responden sebanyak 30 orang. Hasil 30 Penelitian menunjukjan bănwa 25 orang ibu dengan umur tidak berisiko (20-35) 685 ahun sebagian besar responden $(60.0 \%)$ Phengalami nyeri sedang. Pada uji Spearman Rank nilai signifikansi atau Sig. (2-tailed) $0.685>0.05$ dapat diartikan bahwa tidak ada hubungan yang signifikan (berarti) antara variabel umur responden dengan intervensi yang dilakukan. Pada koefisien korelasi sebesar 0.077 artinya, tingkat kekuatan hubungan (korelasi) antara variabel umur responden dengan intervensi yang dilakukan adalah sebesar 0.077 atau korelasi sangat lemah. Nilai koefisien korelasi bernilai positif maka hubungan nyeri dan intervensi searah.

Hasil penelitian ini berbeda dengan penelitian Utami bahwa dari 34 orang responden berada pada rentang usia 20-34 tahun (67.64\%) dan terdapat hubungan usia ibu terhadap penorongn. Usinteryensirbang akan mempengaruhi respon tedilakpkaneri

icientingga dapat disiflplulkan bahwa usia 061 mempengaruhi skala nyeri.

Variabel usia męlpakan hal penting 30 mempengarul61 reaksi maupun000 ekspresi responden.75fhadap nyeri yang dirasakannya, semakin 30eningkat usia maka 30 semakin tinggi reaksi maupun respon nyeri yang dirasakan, usia 20-35 tahun merupakan kelompok usia produktif, dan menghadapi masalah tidak berfokus emosi sehingga memiliki koping yang adaptif (Sharifipour, 2015).

Potter \& Perry, menyatakan bahwa cara seseorang berespons terhadap nyeri dipengaruhi oleh jumlah nyeri yang dialami selama rentang hidupnya. Usia memiliki hubungan dengan pengalaman nyeri seseorang, kelompok anak-anak dan lansia dapat terpengaruh bagaimana cara bereaksi terhadap nyeri. Orang dewasa akan mengalami perubahan neurofisiologis dan mungkin mengalami peningkatan ambang nyeri. ${ }^{12}$

2. Pengaruh Penolong Terhadap Skala Intensitas Nyeri Pada Ibu Bersalin Normal Inpartu Kala I 


\section{Vol. 16 No.2 Mei - Agustus 2021}

Hasil penelitian ini menunjukkan bahwa dari 30 responden, sebagian besar ibu bersalin dengan bidan yang memiliki APN sebanyak (63,3\%). Pada uji Spearman Rank nilai signifikansi atau Sig. (2-tailed) $0.750>$ 0.05 dapat diartikan bahwa tidak ada hubungan yang signifikan (berarti) antara variabel penolong dengan intervensi yang dilakukan. Sedangkan pada koefisien korelasi sebesar 0.061 artinya, tingkat kekuatan hubungan (korelasi) antara variabel penolong dengan intervensi yang dilakukan adalah sebesar 0.061 atau korelasi sangat lemah. Nilai koefisien korelasi bernilai negative, maka hubungan antara variabel penolong dan variabel intervensi yang dilakukan tidak searah.

Hasil penelitian ini berbeda dengan penelitian Fitriana \& Anggista mengatakan bahwa ibu primipara merasakan nyeri yang sangat hebat saat kala I. bahkan pada ibu primipara mengatakan bahwa tidak tahan dengan nyeri yang dirasakan. ${ }^{5}$

Secara umum bersalin dengan bidan yang memiliki APN merupakan persalinan paling aman bagi seorang ibu untuk melahirkan dan masih digolongkan dalam kehamilan resiko rendah. Meskipun demikian tetap ada faktor resiko yang menyebabkan kemungkinan resiko atau bahaya terjadinya komplikasi pada persalinan yang dapat menyebabkan kematian atau kesakitan pada ibu dan bayinya. ${ }^{14}$ 


\section{Pengaruh Kelompok Intervensi dan Kelompok Control Terhadap Penurunan Skala Intensitas Nyeri Pada Ibu Bersalin Normal Inpartu Kala I di PMB Kota Bengkulu}

Berdasarkan hasil uji statistik MannWhitney Test diperoleh perbedaan nilai mean antara perlakuan endorphine massage dan teknik relaksasi nafas dalam sebesar 0.000 , maka secara statistic terdapat pengaruh antara rasa nyeri sesudah diberikan perlakuan endorphine massage dan teknik relaksasi nafas dalam terhadap penurunan skala nyeri pada ibu bersalin normal inpartu kala I di PMB Kota Bengkulu.

Hal ini sejalan dengan penelitian yang dilakukan W Leny \& Machfudloh, Intensitas nyeri pada sebagian besar ibu inpartu kelompok intervensi mengalami nyeri berat sebelum dilakukan endorphine massage sebanyak 6 orang $(30 \%)$ sangat nyeri, 13 orang $(65 \%)$ nyeri berat, dan 1 orang $(5 \%)$ nyeri sedang. Setelah dilakukan endorphine massage terjadi penurunan intensitas nyeri berat sebanyak 6 orang $(30 \%)$ dan nyeri sedang sebanyak 14 orang (70\%). ${ }^{17}$

Pemberian endorphine massage pada ibu bersalin primipara yang dilakukan oleh keluarga masing-masing dilakukan dan tidak dilakukan sebanyak 15 responden $(50 \%)$. Tingkat kecemasan responden yang tidak dilakukan endorphine massage sebagian besar adalah kecemasan besar sebanyak 7 responden (46,7\%). Dan sekelompok ibu yang diberikan endorphine massage tingkat kecemasan sebagian besar adalah kecemasan ringan sebanyak 7 responden $(46,7 \%)$. Dikarenakan endorphine massage merupakan salah satu terapi non-farmakologi untuk mengurangi atau meringankan rasa sakit pada ibu yang akan melahirkan. Sehingga dengan berkurangnya rasa sakit akan dapat menurunkan kecemasan ibu saat bersalin. ${ }^{15}$

Hasil penelitian Novita (2017), menunjukkan hasil uji wilcoxon signed rank test dan diperoleh hasil p-value $0.000<\alpha$ (0.05), maka dapat disimpulkan bahwa Ho ditolak atau adanya pengaruh teknik relaksasi nafas dalam terhadap respon nyeri pada ibu inpartu kala I fase aktif di Puskesmas Bahu Manado.

Relaksasi nafas dalam merupakan bentuk asuhan keperawatan terapi nonfarmakologi yang mengajarkan kepada pasien tentang bagaimana cara melakukan relaksasi nafas dalam. Teknik relaksasi nafas dalam dapat merangsang tubuh untuk melepaskan opioid yaitu endorfin dan enkelaktin. Hormon endorphin merupakan substansi sejenis morfin yang berfungsi sebagai penghambat tranmisi inpuls nyeri. Pada saat neuron nyeri perifer mengirimkan sinyal ke sinaps, terjadi sinapsis antara neuron perifer dan neuron yang menuju otak tempat seharusnya substansi $\mathrm{P}$ akan menghasilkan inpuls. Pada saat itu, endorphin akan memblokir lepasnya substansi $\mathrm{P}$ dari neuron sensorik sehingga sensasi nyeri akan berkurang.

\section{Pengaruh endorphine massage terhadap skala intensitas nyeri pada ibu bersalin kala I fase aktif}

Pada kelompok intervensi perlakuan yang diberikan berupa penurunan skala intensitas nyeri pada ibu bersalin normal inpartu kala I $(p=0.000)$ atau $p<0.05$ yang menunjukkan adanya pengaruh penurunan skala intensitas nyeri pada ibu bersalin sedangkan pada kelompok kontrol dengan teknik relaksasi nafas dalam terhadap skala intensitas nyeri pada ibu bersalin normal $(p$ $=0.001)$ atau $\mathrm{p}<0.05$ yang juga berpengaruh terhadap penurunan skala intensitas nyeri pada ibu bersalin.

Hal ini sejalan dengan penelitian Fitriana \& Anggista, yang menunjukkan ada pengaruh intensitas nyeri terhadap pijat endorphine sebelum dan setelah dilakukan pijat endorphine $(p$ - value $0.006<0.005)$. Dalam penelitiannya terdapat pengaruh terhadap pengurangan intensitas nyeri pada kala I persalinan normal. Hal ini dikarenakan sentuhan dan pijatan dapat memberikan ibu perasaan tenang dan nyaman dalam menghadapi proses persalinan. Selain tidak menimbulkan efek samping yang membahayakan ibu pijat endorphine dapat menurunkan kecemasan sehingga nyeri yang di timbulkan saat bersalin dapat berkurang. Adanya penurunan nyeri ini disebabkan kondisi ibu yang dapat mengendalikan rasa takut dan cemas yang berlebihan, ibu mempunyai persepsi sendiri tentang nyeri persalinan dan melahirkan dan percaya ia dapat mengendalikan nyeri tersebut. ${ }^{5}$

Nyeri persalinan kala I merupakan salah satu proses fisiologis yang disebabkan oleh proses dilatasi serviks, hipoksia otot uterus 


\section{Vol. 16 No.2 Mei - Agustus 2021}

pada saat kontraksi, iskemia korpus uteri, serta peregangan pada segmen bawah rahim dan kompresi saraf di servik. Karena rahim merupakan salah satu organ internal maka nyeri yang timbul disebut nyeri visceral. Pada persalinan nyeri alih dapat dirasakan pada punggung bagian bawah dan sacrum biasanya ibu hanya mengalami rasa nyeri ini selama kontraksi dan bebas dari rasa nyeri pada interval antar kontraksi. ${ }^{9}$

Endorphine massage merupakan sebuah terapi sentuhan atau pijatan ringan yang cukup penting diberikan pada ibu hamil dan saat menjelang melahirkan. Pijatan ini dapat merangsang tubuh untuk melepas senyawa endorphine yang merupakan perede rasa sakit dan dapat menciptakan perasaan nyaman. ${ }^{10}$

Hal ini sejalan dengan penelitian Lusiana \& Handayani yang menunjukkan adanya pengaruh endorphine massage terhadap intensitas skala nyeri kala I Fase aktif persalinan ( $p$ - value $0.000<0.05$ ). dalam penelitiannya terdapat pengaruh penggunaan endorphine massage terhadap skala intensitas nyeri kala I fase aktif persalinan. ${ }^{11}$

Berdasarkan hasil statistik bahwa kelompok intervensi dan kelompok kontrol sama-sama berpengaruh terhadap penurunan skala intensitas nyeri, namun pada kelompok intervensi dengan menggunakan endorphine massage nilai $p$ value $=0.000(<0.05)$ sedangkan pada kelompok kontrol dengan perlakuan teknik relaksasi nafas dalam nilai $p$ value $=0.001(<0.05)$ dengan kesimpulan bahwa ada pengaruh endorphine massage terhadap skala intensitas nyeri pada ibu bersalin normal inpartu kala I.

\section{KESIMPULAN}

Penelitian yang dilaksanakan di PMB Kota Bengkulu pada Februari - Maret 2020 dengan jumlah sampel 30 orang responden dengan desain penelitian quasi eksperimen, diperoleh hasil penelitian $p=0.000$ ( $p<$ 0.05) maka dapat disimpulkan bahwa:

1. Hampir seluruh responden memiliki umur 20-35 Tahun dan penolong persalinan dengan bidan yang memiliki APN.

2. Ada penurunan rata-rata nyeri setelah diberikan intervensi endorphine massage di PMB Kota Bengkulu
3. Ada penurunan rata-rata nyeri setelah diberikan perlakuan teknik relaksasi nafas dalam di PMB Kota Bengkulu

4. Ada perbedaan rata-rata intensitas nyeri pada ibu bersalin kala I fase aktif sebelum dan sesudah di lakukan endorphine massage dan teknik relaksasi nafas dalam di PMB Kota Bengkulu

5. Ada pengaruh kelompok intervensi dan kelompok control terhadap penurunan skala intensitas nyeri pada ibu bersalin normal inpartu kala I di PMB Kota Bengkulu

6. Tidak ada pengaruh antara usia dan penolong terhadap penurunan intensitas skala nyeri.

\section{UCAPAN TERIMA KASIH}

Penulis mengucapkan terima kasih kepada Praktek Mandiri Bidan di Kota Bengkulu sebagai tempat penelitian atas fasilitas yang telah diberikan.

\section{DAFTAR PUSTAKA}

1. Andarmoyo, S. (2013). Persalinan Tanpa Nyeri Berlebihan. Ar-Ruzz Media.

2. Aprillia, Y. (2010). Hipnostetri Rileks, Nyaman, Dan Aman Saat Hamil Dan Melahirkan. Gagas Media.

3. Azizah, Iin Nur; Widyawati, Melyana Nurul; Anggraini, N. N. (2013). Pengaruh Endorphin Massage Terhadap Intensitas Nyeri Kala I Persalinan Normal Ibu Primipara Di Bps S Dan B Demak Tahun 2011. Jurnal Kebidanan, 2(1), 90-96.

4. Felina, M., Masrul, \& Iryani, D. (2015). Artikel Penelitian Pengaruh Kompres Panas Dan Dingin Terhadap Penurunan Nyeri Kala I Fase Aktif Persalinan Fisiologis Ibu Primipara. 4(78), 63.

5. Fitriana, \& Anggista, P. N. (2017). Pengaruh Pijat Endorphin (Endorphin Massage) Terhadap Intensitas Nyeri Kala I Pada Ibu Primipara. Jurnal Ilmiah Keperawatan Sai Betik, Xiii(1), 31-34.

6. Henderson, C. (2010). Buku Ajar Konsep Kebidanan (Essensial Midwifery). Egc. 
7. Humaira, W.H.S.S. (2016). Pengaruh Terapi Musik Klasik Terhadap Intensitas Nyeri Pada Ibu Inpartu Fase Aktif Kala I Persalinan Di Rumah Bersalin Jalan Bromo Kecamatan Medan Area. Jurnal Kesehatan Ilmiah Masuwakes 9.

8. Hutahaean. (2010). Konsep \& Dokumentasi Keperawatan. Trans Info Media.

9. Judha, M. (2012). Teori Pengukuran Nyeri Dan Nyeri Persalinan. Nuha Medika.

10. Kuswandi, L. (2011). Keajaiban Hypno Birthing. Pustaka Bunda.

11. Lusiana, A., \& Handayani, E. (2017). Pengaruh Endorphine Massage Terhadap Skala. 2013.

12. Perry \& Potter. (2010). Fundamental Keperawatan Buku 3 Edisi 7. Salemba Medika.

13. Rahman, S. A., Handayani, A., \& Mallongi, A. (2017). Penurunan Nyeri Persalinan Dengan Kompres Hangat Dan Massage Effleurage. 13(2), 147-
151.

14. Suharti, S. . (2013). Persalinan Tanpa Nyeri Berlebihan: Konsep \& Aplikasi Manajemen Nyeri Persalinan. Ar-Ruzz Media.

15. Sukmaningtyas, W., \& Windiarti, P. A. (2016). Efektivitas Endorphine Massage Terhadap Tingkat Kecemasan Ibu Bersalin Primippara. Bidan Prada, 07(Juni), 53-62.

16. Taqwin. (2018). The Effect Of Deep Breathing Relaxation Techniques On The Intensity Of Maternal Pain During First Laten Phase In Anatapura Midwifery Clinic Taqwin Poltekkes Kemenkes Palu. 12(2), 102-108.

17. W Leny, R. C., \& Machfudloh. (2017). Terapi Endorphin Massage Untuk Menurunkan Intensitas Nyeri Endorphin Massage Therapy To Reduce The Intensity Of Pain During The Active Phase Of Labor Jurnal Smart Kebidanan Sekolah Tinggi Ilmu Kesehatan ( Stikes) Karya Husada Semarang Pendahuluan Nyeri P. 4(2), 1-8. 